\title{
News media making the most of Earth observation satellites
}

\section{Washington \& Paris}

WHEN the French launched the Earthobservation satellite SPOT, in 1986, they thought their customers would be farmers, geologists and land-use planners. Their expectations were met, but they also found demand for SPOT images from an unexpected quarter: the media. Images from SPOT (and from the US Landsat satellites launched earlier) have opened up a whole new set of possiblities for the media, including the chance to look at pictures of Soviet nuclear and radar facilities and have a try at "do-it-yourself arms treaty verification", as a Spot Image representative put it. Demand has been such that there have been calls for the launch of a dedicated "media satellite". This possibility, and the potential conflict between the free availability of images from space and "national security and foreign policy interests" are the subjects of a new report from the US Congress's Office of Technology Assessment.

Over the past two years, US and European media have shown the public SPOT and Landsat images of the Chernobyl nuclear plant, a Soviet naval base on the Kola peninsula, Libyan missile sites, a nuclear processing facility in Pakistan, the Soviet nuclear test facility at Semipalatinsk, the battlefields at the Iran-Iraq border, several Soviet space and airforce bases and the Krasnoyarsk radar in the Soviet Union, which some think violates the terms of the Anti-Ballistic Missile Treaty. Needless to say, none of these places welcomes journalists.

SPOT (Système Probatoire d'Observation de la Terre) has provided the most detailed images. Its resolution is $10 \mathrm{~m}$ in black and white and multi-spectral sensors can help pick out objects that differ in any colour band. Landsats 4 and 5 are capable of $30-\mathrm{m}$ resolution.

Spot Image's policy has always been one of distribution without discrimination: "We sell to anyone, whoever they are, without restriction" according to a spokeswoman at their Toulouse headquarters. Eosat, the private company formed by RCA and Hughes Aircraft to take over the Landsat satellites developed by the US National Aeronautics and Space Administration (NASA) has a similarly liberal view.

From time to time, most recently in a report from the US Commerce Department, the Reagan administration has shown signs of discontent about the uncontrolled flow of information from Earth satellites. Images from SPOT and Landsat are not actually of strategic importance. Both the United States and the Soviet Union have far more powerful spy satel- lites in space. But the media might learn things governments do not announce. Buildup of supplies and troops for military operations (such as the 1983 US invasion of Grenada, for example) could be spotted from space and deprive an operation of the critical element of surprise. Information considered sensitive by foreign governments might also be revealed - construction work at nuclear power plants indicative of weapons development, for example - and make it more difficult for diplomacy to resolve problem. Data might even be misinterpreted by the media and help precipitate a crisis. SPOT images of the nuclear testing facility at Semipalatinsk are said to have been misinterpreted by US television networks as showing that the Soviet Union was about to recommence nuclear testing.

Bigger mistakes, at times of tension, could help trigger a conflict, according to the report. But satellite data also provide a means of checking public statements. The US administration's claims that the Soviet Union has violated nuclear arms treaties has been disputed from satellite image analysis as well as from seismic data.

SPOT and Landsat have disadvantages for news gathering. Neither can provide coverage in real time. Images of Chernobyl were obtained 24 hours after the accident there, but only because there hap-

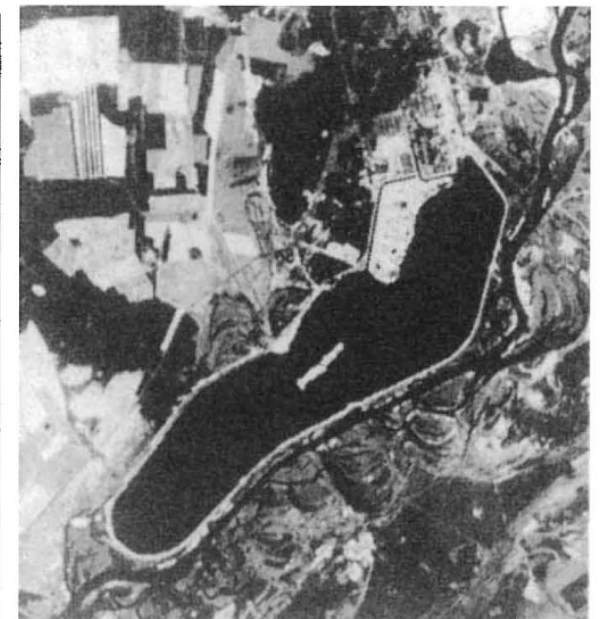

Within $24 \mathrm{~h}$ the Western media had this Landsat image of the stricken Chernobyl plant (centre of the rectangular-shaped area).

pened to be a satellite in position and because other activities were suspended. Rapid news gathering would need a minimum of two 'Mediasat' satellites and either a chain of ground stations or datarelay satellites in space, according to the report. Resolution would also probably have to be improved, to a minimum of 5 $\mathrm{m}$. But a Mediasat would be very expensive and is unlikely to be built in the near future, according to the report. That leaves some time to work out legal problems of a public eye in the sky.

Alun Anderson \& Peter Coles

Commercial Newsgathering from Space, OTATM-ISC-40, is published by the Office of Technology Assessment, Congress of the United States, 27 May 1987.

\section{Mutual assurance for space launches}

Paris

WITH the failure of two of the last four Ariane launches, failures in the US Delta and Titan rockets and the explosion of the Challenger space shuttle, all during a 12month period, the space insurance market is licking its wounds. Having already settled record claims during the previous 12 months, the market may never fully recover. Satellite corporations are now thinking of ways to beat insurance companies, weighed down with losses, at their own game.

Space-insurance brokers have had to fix a ceiling of about $\$ 100$ million on the total risks they are willing to underwrite, while asking a hefty premium, often as high as 25 per cent. Although Arianespace, responsible for the production and marketing of Europe's Ariane rocket launchers, has formed its own insurance subsidiary (S3R) with more attractive rates for its customers, some companies may boycott the insurance market altogether. The most radical option, not to insure the satellite at all, has already been taken for some of the previous Ariane launches.
A more prudent alternative, now under discussion between the bigger, international corporations, such as Eutelsat, Inmarsat and Intelsat, is to create a mutual insurance society, where each member puts a given sum into a kitty for every launch any member has booked. If the launch fails, the costs are shared between members up to a previously agreed limit. If, on the other hand, the launch succeeds, the 'premium' is held over for the next launch and so on. Given the current risk, for example, such a system would enable members to absorb one failure in four at a far lower cost than if a separate premium were paid to an outside company each time.

In the long term, all depends on the failure rate of the next few launches, not only of Ariane but also of Soviet and Chinese competitors. It is almost inconceivable that losses will continue to occur at the rate of the past three years. A series of successes would bring premiums down again, making these radical alternatives to conventional insurance less attractive.

Peter Coles 